\title{
THE MOST COMMON ALLERGIC DISEASES IN DOGS
}

Department of Animal Genetics and Horse Breeding, Siedlce University of Natural Sciences and Humanities, Poland

\begin{abstract}
Allergies affect not only people, but animals as well, including dogs. Allergic diseases are often observed in veterinary practice. There are many factors and substances in the environment around us that can cause allergic reactions. These are known as allergens. They may be of plant or animal origin, but may also be chemical compounds. Allergies in dogs have become a common topic of discussion in veterinary surgeries. Many dogs, purebred or of mixed breeds, are diagnosed for allergies. There are many reasons for the occurrence of allergies, from genetic predisposition to the environmental conditions in which the animal lives. Allergies in dogs are troublesome because when diagnosed too late or left untreated they can lead to serious health complications.
\end{abstract}

Key words: dog, allergy, allergen.

\section{INTRODUCTION}

Allergies affect not only people, but animals as well, including dogs. Allergic diseases are often observed in veterinary practice. There are many factors and substances in the environment around us that can cause allergic reactions. These are known as allergens. They may be of plant or animal origin, but may also be chemical compounds. Depending on the allergen and the body's reaction, different types of allergies are distinguished.

An allergy is hypersensitivity with a basis in immune mechanisms. These mechanisms are mediated by antibodies or inflammatory cells. This is the body's immune response to foreign substances, i.e. allergens. Specific antibodies are then produced and bind to the antigen, leading to the production of mediators responsible for inflammation (Szczepanik et al. 2014; Mueller et al. 2016).

In dogs, allergies are a troublesome disease, because when diagnosed too late or left untreated they can lead to serious health complications. For example, allergic reactions that cause itchy skin lesions may result in open wounds due to the dog's constant scratching. Therefore, it is important to consult a veterinarian about any worrying skin reactions in a dog as soon as possible.

Discussion of allergies should also include atopy, which is a general term for the early type allergic reaction, with mainly dermatological and respiratory symptoms. Atopy is determined genetically and by breed. It is an abnormal immune response to allergens which

Corresponding author: Katarzyna Andraszek, Departament of Genetics and Horse Breeding, Siedlce University of Natural Sciences and Humanities, Bolesława Prusa 14, 08-110 Siedlce, Poland, e-mail: katarzyna.andraszek@uph.edu.pl 
causes the body to produce excessive amounts of IgE antibodies. It was previously thought that the main routes of absorption of allergens were the airways, but the latest research indicates that allergens penetrating the digestive tract or skin have a greater impact on the body (Niemand 2015).

Four types of allergic reactions are most frequently identified:

A. Type I

This type of allergy is usually referred to as an early allergic reaction. The pathological reaction occurs during the second contact with the antigen. The reaction is immediate or occurs a few minutes after contact with a specific antigen. This pathological mechanism is based on spontaneous degranulation of mast cells with $\lg E$ receptors on their surface, which results in the release of granules. The substances released cause clinical symptoms.

Diseases included in this type of reaction include the following:

- atopy,

- flea allergy dermatitis,

- food allergy,

- drug intolerance.

B. Type II

In this type of allergic reaction, antibodies are produced that are directed against the constituent parts of the cell or against the cell membranes. For this reason it is also called a cytotoxic reaction. Factors such as viruses, bacteria or medications can cause an immune response that takes the form of haemolytic anaemia.

C. Type III

This reaction involves antigen-antibody complexes, also called immune complexes. These complexes occur naturally in the body, constantly forming and disintegrating, without causing any clinical symptoms. Disorders occur as a result of systemic or local reactions. Two clinical forms are distinguished:

- arthus reactions, i.e. local tissue damage by immune complexes,

- serum sickness, i.e. inflammatory lesions in the endothelium causing symptoms such as endocarditis, arthritis, vasculitis or glomerulonephritis.

D. Type IV

This is known as delayed-type hypersensitivity. In contrast with the previous types, it is not caused by antibodies but by sensitized T cells ( $T$ lymphocytes). It is referred to as 'delayed' because the reaction is manifested after $24-48$ hours. This type includes the following:

- contact allergy,

- flea allergy,

- reactions to parasite infection.

\section{ATOPIC DERMATITIS}

Atopic dermatitis is genetically-determined inflammation with pruritus. Lesions occurring in specific places on the dog's body are characteristic. This inflammation is very often associated with allergies to environmental allergens, i.e. inhalant allergens, which are present in the air (Hallwell 2006). Diagnosis of this disease cannot be made immediately after questioning the dog's owner about its medical history (De Boer and Hillier 2001). This is 
due to the diversity of the clinical picture, which may depend on genetic factors, the extent of the lesions, the stage of the disease (acute or chronic) and the presence of secondary microbial infections or other symptoms (Wilhem et al. 2001; Nutall 2013). It is one of the most common immune disorders and one of the most commonly clinically diagnosed diseases, affecting about $10-15 \%$ of the canine population (Griffin et al. 2001). According to the latest research, disorders can be detected in dogs with no apparent clinical manifestations of this disease. It is currently believed that allergens mainly penetrate the body via the skin (Cork et al. 2009; Marsella et al. 2012). A continuous reaction to allergens leads to the stimulation of Th2 lymphocytes and the development of dermatitis (Kondo et al. 1998; Boralevi et al. 2008; Szczepanik and Wilkołek 2012; Glatz et al. 2015). This results in impaired production and breakdown of ceramides and other structural elements found in the epidermis (Cork et al. 2009; Marsella et al. 2012). Therefore, when discussing this disease, it is important to take into account disorders of the epidermis, which facilitate access of allergens to the dog's body.

The literature often mentions breed predispositions to atopic dermatitis. The susceptible breeds are mainly golden retrievers, boxers, labradors and terriers, but the disease is also found in other breeds of dogs, as well as mixed breeds. To establish that a dog is susceptible to this disease, it is important to know its age. Symptoms of atopy should appear before the third year of its life. This is closely linked to the genetic background of atopic dermatitis (Niemand 2015; Mueller et al. 2016).

The main allergen of this disease is dust mites present in the environment. Dogs living inside homes are said to be more vulnerable to atopic dermatitis caused by mites than dogs living in kennels outside the house. This is due to the greater concentration of mites in the bedroom and kitchen than outside the home. The main symptom of atopic dermatitis is pruritus, located primarily on the head (eyes, lips and ears), on the feet (interdigital spaces), and in the inguinal region. Dogs intensively lick and scratch the itchy spots, often leading to various complications, such as bald spots, scabs or papules following purulent inflammations of the skin. However, skin lesions may also be caused by other diseases, so the typical location of skin lesions cannot be the only identifying symptom (Kucharski 2015). Diagnosis of atopic dermatitis should be based on medical history, clinical symptoms and additional tests to rule out other skin diseases that may have similar symptoms (Shaw et al. 2004; Szczepanik et al. 2010a,b).

One of the most common complications of atopy is recurrent and chronic yeast dermatitis. This inflammation causes excessive multiplication of yeasts Malassezia spp. Their proliferation creates extensive skin inflammations together with erythema, pruritus and lichenification (Wilkołek 2017).

To determine whether the symptoms are typical of atopic dermatitis, serological and intradermal tests are initially discouraged in the initial stage of diagnosis, as they may give false results. It is recommended to first rule out parasitic (internal and external) infections and food allergies (Olirry et al. 2010; Niemand 2015). If the tests rule out these diseases and atopic dermatitis is confirmed, then treatment can be begun. Local or systemic treatments with appropriate anti-inflammatory drugs are used. If the skin lesions are recurrent or chronic, allergy tests are recommended to identify the allergens, after which specific immunotherapy, called desensitization, can be introduced. This disease can also be treated with appropriate 
medications that are individually tailored to the dog. It is also important to use shampoo therapy, with appropriate ingredients selected by a veterinary surgeon, as well as antipruritic conditioners and ceramide replacement products (Jeronim 2014). In addition, studies show that a diet containing polyunsaturated fatty acids can alleviate the symptoms of atopic dermatitis, making it possible to reduce the dose of glucocorticoids (Saevic et al. 2004; Glos et al. 2007). The effectiveness of dietary supplementation depends on the stage of the disease. Dogs in the early stage of the disease respond better to diet (Abba et al. 2005). An eight-week study conducted on 50 dogs with atopic dermatitis, testing the effectiveness of four different diets, showed that dogs fed a fish diet had significantly less pruritus than those fed other diets (Glos et al. 2007).

\section{FOOD ALLERGY}

Food allergy is one of the most commonly diagnosed allergic skin diseases in dogs (Szczepanik et al. 2014; Mueller et al. 2016). There is a theory that in puppies, i.e. dogs under one year of age, allergic reactions to food are more common than allergic reactions to environmental allergens (Picco et al. 2008; Corlotti 2014). The cause of this allergy is the development of immediate-type hypersensitivity, but it has been suggested that types III and IV hypersensitivity may also be involved (Scott et al. 2001). Research indicates that neither the age nor the sex of a dog is relevant to the occurrence of the disease. There are breeds with a predisposition to this allergy, i.e. boxers, pugs, german shepherds, west highland white terriers, and rhodesian ridgebacks, but the disease is also found in other breeds of dogs and in mixed breeds.

Food allergies can be caused by a variety of substances, but are mainly caused by glycoproteins found in products such as poultry, beef, soy, maize, cereals, cow milk, fish, eggs, rice and potatoes (Martin et al. 2004; Day 2005; Ohmori et al. 2005; Verlinden et al. 2006). However, additional substances used in the production of food products and commercial pet food are also suspected of being involved in the development of food allergies (Córdowa Moreno and Trigo Tavera 1999; Kucharski 2011).

One of the main clinical symptoms of food allergy is severe pruritus, which is independent of the time of year. Skin lesions can be observed in the form of pustules or papules and erythema in the inguinal region and on the abdomen. Other symptoms are dermatitis, inflammation of the outer ear, recurrent purulent dermatitis, eosinophilic vasculitis, urticaria, and seborrhoea. Gastrointestinal symptoms are usually observed. Symptoms may be mild or below the pruritic threshold, or isolated pruritic episodes may occur (Lewis 2017).

Distinguishing between food allergy and atopic dermatitis is quite problematic. There is research showing that a clue in distinguishing between the two diseases is the dog's reaction to the administration of glucocorticosteroids, as these drugs are effective against atopic dermatitis. If pruritus persists despite the medication, then the possibility of food allergy may be considered (Lewis 2017). However, many doctors and scientists are uncertain about the results of this research. Serological or intradermal tests do not produce reliable results, because the breakdown and metabolic products of foodstuffs can also be sensitizing, resulting in false results of these tests (Niemand 2015; Mueller et al. 2016). 
The only valid and effective method of diagnosing food allergy is the use of an elimination diet followed by a provocation test, using food that is suspected of causing the allergy symptoms. This diet should include sources of protein, carbohydrates and fat that have previously not been used. It can be based on horse meat, venison, lamb, turkey, duck or fish. It is important that the diet should have a single source of protein. The dog should be gradually accustomed to the change in food to avoid digestive complications (Jackson 2001; Morariu et al. 2010). The new diet should be introduced over 3 to 5 days, and the elimination diet itself should be used for 4 to 6 weeks, extended to 10-13 weeks if necessary (Szczepanik et al. 2014). According to research, when an elimination diet was extended to about 8 weeks, clinical symptoms disappeared in nearly all dogs tested (Mirowski 2014).

Once the clinical symptoms resolve, provocation tests can be introduced. These consist in the addition to the elimination diet of a single ingredient that the dog had received in its previous diet, before the start of the treatment. Clinical symptoms indicating an allergy to the added ingredient will appear within 2 to 48 hours after ingestion. It is important to observe the dog for about 2 weeks, because some forms of food allergy involve delayed-type reactions, whose symptoms appear later (Wills et al. 1994). If there are no signs of sensitization by that time, another ingredient used before the elimination diet may be added. In this way, after each ingredient that the dog was fed before the elimination diet has been added, we have a list of ingredients to which the dog is allergic and of those it can continue to eat (Jackson 2001).

It is important that the dog does not receive any treats, vitamin preparations, or antibiotics in the form of tablets or capsules at any time during the entire treatment, so as not to distort the results of the elimination diet. The elimination diet can be prepared at home, or commercial hypoallergenic food can be used. There are two types of such food. One is based on hydrolysed protein with a lower molecular weight, but it is less palatable to the dog. The second type, made from a single source of protein, is more readily accepted by dogs. However, research suggests that commercial pet foods are not always as 'healthy' as they should be, because they often contain additional ingredients which may not be listed on the label, and these may be additional allergens for the dog (Mueller et al. 2016; Lewis 2017).

After the allergens causing the reaction have been identified, the dog can be fed the food used before the elimination diet, except for the allergenic ingredients. However, it should be borne in mind that the diet without these allergenic ingredients may cease to be effective and clinical symptoms of food allergy may reappear. This is because dogs may become allergic to other food ingredients. Then the treatment based on the elimination diet should be resumed (Szczepanik et al. 2014; Mueller et al. 2016).

\section{ALLERGIES TO PARASITES AND BITING INSECTS}

Some of the external parasites living on a dog can be seen with the naked eye. These are primarily fleas, whose saliva components, specifically the proteins contained in it, can lead to flea allergy dermatitis after the dog has been bitten. This disease develops due to Type I and Type IV hypersensitivity to allergens found in flea saliva (Ready et al. 1997; Scott et al. 2001; Griffin 2008). Clinical symptoms of flea allergy dermatitis appear seasonally from spring to autumn, when these parasites multiply. The disease affects animals of all ages, irrespective of sex or breed. There is a theory that puppies given flea protection too early are more 
susceptible to this disease. This is because the young organism will not acquire immunity to the antigens contained in flea saliva. For this reason, flea protection products should be used at a later age.

Antigens contained in the secretions of fleas can cause severe allergic reactions. Four stages of the reaction are distinguished (Taszkun and Śmiech 2006):

- pruritus - pruritus affecting the skin in the lumbar region, sacral region, abdomen, thighs, and sometimes also the head,

- erythema and pruritus - pruritus as above with additional erythema,

- self-injury - secondary lesions following pruritus, oozing purulent skin damage,

- chronic disease resulting from the allergy - lichenification of the skin.

Flea allergy dermatitis is diagnosed by means of intradermal tests using flea antigen and skin biopsy. The histopathological picture of the skin sample varies depending on the stage of the disease. The histopathological picture for the pruritus and erythema and pruritus stages is the least characteristic for flea allergy dermatitis (Kramer and Mencke 2001). The most reliable diagnosis of the disease is provided by an image of a skin sample on which erythema and papules are visible (Taszkun and Śmiech 2006).

The best means of preventing the allergic reactions of flea allergy dermatitis is appropriate prophylaxis, which consists in using anti-flea preparations in the form of spot-on drops or special shampoos, sprays or collars. It is important to use anti-flea prevention regularly throughout the year, and not only in the spring and autumn. This increases the chance of controlling an infestation of fleas in the dog's environment. It is also worth noting that fleas are intermediate hosts of tapeworms, so regular prevention of their occurrence also reduces the occurrence of internal parasites in animals (Niemand 2015; Mueller et al. 2016).

Very similar consequences and clinical symptoms are observed in the case of allergy to the venom of ticks, mosquitoes, flies, mites, wasps and bees. This disease usually occurs in warm months, when insects become active and search for hosts. It is relatively difficult to distinguish from other allergies. Intradermal tests with appropriate antigens are used for diagnosis. Accurate identification of an allergen-carrying insect allows for appropriate prophylaxis, e.g. spot-on preparations against ticks or mites (Niemand 2015; Mueller et al. 2016).

Insect stings usually result in urticaria, ulcerations, oedema and scabs. Generalized reactions have not been recorded in dogs as a consequence of bites or stings. It is also difficult to establish age and breed predispositions due to the rarity of this type of complication following a sting (Prelaud 2008).

Tick bites usually cause erythematous reactions. Some individuals have granulomatous reactions accompanied by pruritus. These reactions can become ulcerated or can spread to larger areas of the body. Experiments have shown that following a tick bite on the dog's body, an immediate-type hypersensitivity reaction develops (Prelaud 2008).

In the case of ticks, prophylactic use of a repellent collar, tablets or spot-on preparations is recommended, but no effective repellent against flies or mosquitoes has been devised.

\section{CONTACT ALLERGY}

Another immune-mediated disease is allergic contact dermatitis. This is a type IV hypersensitivity allergy (Szczepanik et al. 2010a, b; Szczepanik and Wilkołek 2012; Niemand 2015). It accounts for only $10 \%$ of dermatological disorders (Thomsen and Thomsen 1989). This disease is caused by direct skin contact with environmental substances. After repeated 
contact, allergens lead to sensitization of T lymphocytes (Niemand 2015). The time interval between the allergen's contact with the skin and an allergic reaction ranges from 12 to 72 hours. The manifestation of clinical symptoms is preceded by an induction phase, which can last from 6 months to even 2 years (Marsella et al. 1997).

Research has not shown any gender predisposition to this disease. It more frequently affects adult dogs and the breeds German Shepherd, Golden Retriever, Poodle, Fox Terrier, Scottish Terrier, and West Highland White Terrier (Gross et al. 2005), but mixed breeds may suffer from it as well. Allergens causing this disease include the following (Szczepanik et al. 2010a, b; Szczepanik and Wilkołek 2012; Niemand 2015):

- plants: camellia, chrysanthemum, primrose, dahlia, dandelion, pine and other conifers, ivy, Liliidae, spiderwort, amaryllis, cedar;

- medicines: streptomycin, neomycin, gentamicin, spectinomycin, chlorhexidine, glucocorticoids, Balsam of Peru, benzoyl peroxide;

- metals: nickel and chromium (in dog collars);

- others: herbicides, detergents, formaldehyde, rubber, disinfectants, synthetic fabrics, shampoos, insecticides, terpene lactones, tea tree oil.

Clinical symptoms are most common in areas where the hair coat is thin, such as the axillae, abdomen, groin, anal area, scrotum and the underside of the feet. If the dog has an allergic reaction to medicines, it will be visible at the site of application, e.g. in the outer part of the ear canal. The symptoms of allergic contact dermatitis include papules, erythema, ulcerations, scabs and lichenification. A clear border can be seen between the healthy skin and the skin with the allergic reaction. Bacterial infections, seborrheic dermatitis and Malassezia infection may also accompany this disease (Mueller et al. 2016).

One of the problems in diagnosing allergic contact dermatitis is that the symptoms are very similar to those of irritant contact dermatitis. The difference between these diseases is that allergic dermatitis is an immune disease mediated by the body's defence mechanisms, whereas irritant contact dermatitis develops when the skin comes in contact with an irritant. Damage occurs due to contact with a substance that has a toxic effect on the skin. Unfortunately, the clinical symptoms of the two diseases are very similar and quite difficult to distinguish. For this reason, tests diagnosing allergic contact dermatitis are not fully reliable, since, according to researchers, the results may also be indicative of atopic dermatitis. Patch tests can be used for diagnostic purposes. These tests involve placing patches saturated with the test substance on the dog and then observing any skin changes that occur. Unfortunately, the test is somewhat difficult to carry out, because the patches must remain on the dog's body for 48 hours. In a study in which these tests were carried out on a group of dogs, in $83.3 \%$ of healthy dogs they had false positive results, i.e. the substances in the patches had an effect indicating that they were allergic to these substances (Scott et al. 2001). One of the most effective means of diagnosing allergic contact dermatitis is the provocation method. This involves separating the dog from its living environment for two weeks and then bathing it with a special hypoallergenic shampoo to remove irritant particles. After two weeks the animal is returned to its living environment. However, this method also does not confirm this disease with complete certainty. Its results may also be indicative of atopic dermatitis or irritant contact dermatitis (Scott et al. 2001; Szczepanik et al. 2010a, b; Szczepanik and Wilkołek 2012). 
After the disease has been diagnosed, the most important step is to eliminate the substance that irritates the dog's body from the environment. It is also important to remove the substance from the surface of the animal's body by bathing it with hypoallergenic shampoo. If it is not possible to remove the allergen from the environment, then glucocorticosteroids are administered to alleviate clinical symptoms (Szczepanik et al. 2010a, b; Szczepanik and Wilkołek 2012).

There are a great many factors influencing the occurrence of allergies in dogs. However, most studies confirm that the environment is the main determinant of tendencies for allergic reactions in dogs. The main allergens causing concern to animal owners, not only in Poland but around the world, are dust mites. Therefore, it is important that the dog should have contact with various animals from its earliest moments of life and be kept in a suitable environment that will strengthen the immune system, thereby reducing the tendency for allergic reactions.

\section{CONCLUSIONS}

There are a great many factors influencing the occurrence of allergies in dogs. However, most studies confirm that the environment is the main determinant of tendencies for allergic reactions in dogs. The main allergens causing concern to animal owners, not only in Poland but around the world, are dust mites. Therefore, it is important that the dog should have contact with various animals from its earliest moments of life and be kept in a suitable environment that will strengthen the immune system, thereby reducing the tendency for allergic reactions.

\section{REFERENCES}

Abba C., Mussa P.P., Vercelli A., Raviri G. 2005. Essential fatty acids supplementation in differentstage atopic dogs fed on a controlled diet. J. Anim. Physiol. Anim. Nutr. (Berl) 89, 203-207.

Bjelland A.A., Dolva F.L., Nødtvedt A., Sævik B.K. 2014. Prevalence of and risk factors for increased serum levels of allergen-specific IgE in a population of Norwegian dogs. Acta Vet. Scand. $56,1-11$.

Boralevi F., Hubicke T., Leante-Labrze C., Sanbusse E., Fayon M., Roul S. 2008. Epicutaneous aeroallergen sensitization in atopic dermatitis infants - determining the role of epidermal barrier impairment. Allergy 63, 205-210.

Cork M.J., Danby S.G., Vasilopoulos Y., Hadgraft J., Lane M.E., Moustafa M., Guy R.H., Macgowan A.L., Tazi-Ahnini R., Ward S.J. 2009. Epidermal barrier dysfunction in atopic dermatitis. J. Invest. Darmatol. 129, 1890-1908.

Corlotti D.N. 2004. Cutaneous manifestations of food hypersensitivity. Veterinary allergy. Chichester, UK, Wiley Blackwell, 15, 349-356.

Córdowa Moreno E., Trigo Tavera E.J. 1999. Hipersensibilidad alimentaria canina. Vet. Mex. 30, 67-77.

Day M.J. 2005. The canine model of dietary hypersensitivity. Proc. Nutr. Soc. 64, 458-464.

DeBoer D.J., Hillier A. 2001. The ACVD task force on canine atopic dermatitis (XV): fundamental concepts in clinical diagnosis. Vet. Immunol. Immunopathol. 81, 271-276.

Glatz M., Bosshard P.P., Hoetzeuecher W., Schimol-Grendelmeier P. 2015. The role of Mallassezia spp in atopic dermatitis. J. Clin. Med. 4, 1217-1228. 
Glos K., Linek M., Loewenstein C., Mayer U., Mueller R.S. 2007. The efficacy of commercially available veterinary diets recommended for dogs with atopic dermatitis. Vet. Dermatol. 19, 280-287.

Griffin C.E. 2008. Current veterinary dermatology. Mosby, Maryland Heights, Missouri, USA.

Griffin C.E., DeBoer D.J. 2001. The ACVD task force on canine atopic dermatitis (XIV): clinical manifestations of canine atopic dermatitis. Vet. Immunol. Immunopathol. 81, 255-269.

Gross T.L., Ihrke P.J., Walder E.J., Affolter V.K. 2005. Skin diseases of the dog and cat: clinical and histopathologic diagnosis. Chichester, UK, Wiley-Blackwell.

Hallwell R. 2006. Revised nomenclature for veterinary allergy. Vet. Immunol. Immunopathol. 114, 207-208.

Jackson H.A. 2001. Diagnostic techniques in dermatology: The investigation and diagnosis of adverse food reactions in dogs and cats. Clinic Tech. Small Anim. Pract. 16, 233-235.

Jeronim A.M. 2014. Wskazówki pomocne w skutecznym leczeniu atopii u psów [Helpful tips for successful treatment of atopy in dogs]. Weter. Dypl. 5, 38-41. [in Polish]

Kondo H., Ichikawa Y., Imokawa G. 1998. Percutaneous sensitization with allergens through barrierdisrupted skin elicits a Th2-dominant cytokine response. Eur. J. Immunol. 28, 769-779.

Kramer F., Mencke N. 2001. Flea biology and control Springer. Verlag, Berlin.

Kucharski M. 2011. Alergeny pokarmowe [Food allergens]. Weter. Prakt. 8, 58-61. [in Polish]

Kucharski M. 2015. Od alergenu do atopowego zapalenia skóry u psów [Since the allergen to atopic dermatitis in dogs]. Weter. 6, 26-29. [in Polish]

Lewis T. 2017. Rozpoznanie alergii pokarmowej u psów i kotów [Diagnosis of food allergy in dogs and cats]. Weter. Dypl. 18, 34-36. [in Polish]

Marsella R., Kunkle G. A., Lewis D.T. 1997. Use of pentoxifylline in the treatment of allergic contact reactions to plants of the Commelinceae family in dogs. Vet. Dermatol. 8, 121-126.

Marsella R., Sousa C.A., Gonazales A.J., Fadok V.A. 2012. Current understanding of the pathophysiologic mechanisms of canine atopic dermatitis. J. Am. Vet. Med. Assoc. 241, 194-207.

Martin A., Paz Sierra M., Gonzales J., Angelles A.M. 2004. Identification of allergens responsible for canine cutaneous adverse food reactions to lamb, beef and cow's milk. Vet. Dermatol. 15, 349-356.

Mirowski A. 2010. Postępowanie żywieniowe w alergii pokarmowej u psów i kotów [Nutrition in canine and feline food allergy]. Życie Weter. 3, 221-223. [in Polish]

Morariu S., Dărăbuş GH., Oprescu I., Mederle N., Ilie M.S., Dăboveanu C. 2010. Actualities in diagnosis of food allergy dermatitis. Lucrari Stiint. Med. Veter. 43, 13-20.

Mueller R.S., Janda J., Jensen-Jarolim E., Rhyner C., Marti E. 2016. Allergens in veterinary medicine. Allergy 71, 27-35.

Niemand H.G. 2015. Praktyka kliniczna: psy. Łódź, Wydaw. Galaktyka. [in Polish]

Nutall T. 2013. The genomic revolution will canine atopic dermatitis be predictable and preventable? Vet. Dermatol. 24, 13-14.

Ohmori K., Masuda K., Ohno K., Sakaguchi M., Tsujimoto H. 2005. Bovine serum albumin is one of common allergens in dogs with spontaneous beef allergy J. Allergy Clin. Immunol. 115(2), S243.

Olirry T., DeBoer D.J., Favrot C., Jackson H.A., Mueller R.S., Nuttall T., Prelaud P. 2010. Treatment of canine atopic dermatitis: 2010 clinical practice guidelines from the International Task Force on Canine Atopic Dermatitis. Vet. Dermatol. 21, 233-248.

Picco F., Zini E., Nett C., Naegeli C., Bigler B., Rufenacht S., Roosje P., Gutzwiller M.E., Wilhelm S., Pfister J., Meng E., Favrot C. 2008. A prospective study on canine atopic dermatitis and food-induced allergic dermatitis in Switzerland. Vet. Dermatol. 19, 150-155.

Prelaud P. 2008. Choroby alergiczne psów. Wrocław, Wydaw. Med. Urban and Partner. [in Polish]

Ready L.M., Miller W.H., Willemse T. 1997. Allergic skin diseases of dogs and cats. 2nd ed. Philadelphia, US, Saunders Ltd. 
Saevic B.K., Bergvall K., Holm B.R., Saijonmoa-Koulumies L.E., Hedhammar A., Larsen S., Kristensen F. 2004. A randomized, controlled study to evaluate the steroid sparing effects of essential fatty acid suplementation in the treatment of canine atopic dermatitis. Vet. Dermatol. 15, 137-145.

Scott D.W., Miller W.H. 1993. Nonsteroidal anti-inflammatory agents in the management of canine allergic pruritus. J. S. Afr. Vet. Assoc. 64, 52-56.

Scott D.W., Miller W.H., Griffin C.E. 2001. Small animal dermatology. Philadelphia, US, W.B. Saunders Company, 615-627.

Shaw S., Wood J.L., Freeman I., Littlewood J.D., Hannant P. 2004. Estimation of heritability of atopic dermatitis in Labrador and Golden Retrivers. Am. J. Vet. Res. 65, 1014-1020.

Szczepanik M., Wilkołek P. 2012. Rola zaburzeń bariery skórnej w atopowym zapaleniu skóry u psów [Skin barier dysfunction in canine atopic dermatitis]. Życie Weter. 87, 672-674. [in Polish]

Szczepanik M., Adamek Ł., Wilkołek P. 2010a. Diagnostyka atopowego zapalenia skóry u psów oraz ocena obrazu klinicznego choroby [Diagnosis of canine atopic dermatitis and the clinical score of the disease]. Życie Weter. 85, 332-337. [in Polish]

Szczepanik M., Śmiech A., Zadrzyńska K., Wilkołek P. 2010b. Kontaktowe zapalenie skóry u psów i kotów - przyczyny, rozpoznanie i leczenie [Allergic contact dermatitis in dogs and cats - causes, diagnostic methods and treatment]. Życie Weter. 85, 921-924. [in Polish]

Szczepanik M., Wilkołek P., Chmielecka K. 2014. Alergia pokarmowa u psów i kotów [Food allergy in dogs and cats]. Mag. Weter. 23, 20-24. [in Polish]

Taszkun I., Śmiech A. 2006. Zmiany histopatologiczne skóry w chorobach alergicznych u psów [Histopathological changes of the skin in allergic diseases of dogs]. Życie Weter. 81, 538-543. [in Polish]

Thomsen M.K., Thomsen H.K. 1989. Histopathological changes in canine allergic contact dermatitis patch test reactions. A study on spontaneously hypersensitive dogs. Acta. Vet. Scand. 30, 37-384.

Verlinden A., Hesta M., Millet S., Janssens G.P. 2006. Food allergy in dogs and cats. Crit. Rev. Food Sci. Nutr. 46, 259-273.

Wilhem S., Kovalik M., Favrot C. 2001. Breed-associated phenotypes in canine atopic dermatitis. Vet. Dermatol. 22, 143-149.

Wilkołek P. 2017. Ocena kliniczna skuteczności wielokierunkowego leczenia psów z atopowym zapaleniem skóry i wtórym zespołem keratołojowotkowym [Assessment of efficacy of multidirectional combination topical therapy in dogs with atopic dermatitis and secondary seborrhea]. Weter. Prakt. 10, 94-98. [in Polish]

Wills J., Harvey R. 1994. Diagnosis and management of food allergy and intolerance in dogs and cats. Aust. Vet. J. 71, 322-326.

\section{NAJCZĘSTSZE CHOROBY ALERGICZNE U PSÓW}

Streszczenie. Alergie, wbrew pozorom, to nie tylko dolegliwości dotykające ludzi, ale również zwierzęta, np. psy. Choroby alergiczne są często obserwowane w praktyce weterynaryjnej. W otaczającym nas środowisku istnieje wiele czynników i substancji, które mogą wywoływać reakcje uczuleniowe; są to alergeny. Mogą one mieć pochodzenie roślinne bądź zwierzęce, ale mogą być również związkami chemicznymi. Alergie u psów stały się stosunkowo częstym tematem dyskusji podejmowanym w gabinetach weterynaryjnych. Wiele psów, bez względu na to, czy są to psy rasowe czy nie, jest diagnozowanych w kierunku alergii. Powodów występowania alergii jest wiele - od predyspozycji genetycznych do warunków środowiskowych, w jakich zwierzę funkcjonuje. Dla psów alergia jest dokuczliwą chorobą; późno zdiagnozowana bądź nieleczona może doprowadzić do poważnych powikłań zdrowotnych.

Słowa kluczowe: pies, alergia, alergen. 